\title{
Industrial growth and consumer goods inflation in Mexico: an econometric analysis
}

\author{
Víctor Manuel Cuevas Ahumada \\ and Cuauhtémoc Calderón Villarreal ${ }^{1}$
}

\begin{abstract}
This paper employs a vector error correction methodology to investigate the long-term determinants of consumer goods inflation and industrial growth in Mexico during the 2001-2016 period. This is underpinned by a aggregate demand-aggregate supply model that brings new explanatory variables into play and keeps a priori restrictions on the data to a minimum. The evidence shows that cost-push and demand-pull inflation are both present and reveals the variables at work in each case. This study fills a gap in the empirical literature by showing that labour productivity not only spurs industrial growth, but also lowers consumer goods inflation in the long run. The policy implication of this finding is important given the need to attain faster economic growth without sacrificing price stability.
\end{abstract}

\section{Keywords}

Industrial production, inflation, consumer goods, economic analysis, econometric models, Mexico

JEL classification

C32, F41, J24

\section{Authors}

Víctor Manuel Cuevas Ahumada is a Research Professor in the Economics Department of the Metropolitan Autonomous University, Azcapotzalco Unit, Mexico. Email: victorcuevasahumada@yahoo.com.mx.

Cuauhtémoc Calderón Villarreal is a Research Professor in the Economic Studies Department of El Colegio de la Frontera Norte, Mexico. Email: calderón@colef.mx.

1 The authors are grateful for the valuable comments and suggestions made by an anonymous referee. 


\section{Introduction}

This paper uses a vector error correction (VEC) approach to study the long-run determinants of industrial growth and consumer goods inflation in Mexico during the 2001-2016 period. The VEC model embodies an aggregate demand-aggregate supply specification that includes a fairly wide range of variables to keep a priori restrictions on the data to a minimum. This specification is consistent with a small open economy with a flexible exchange rate. It also incorporates some previous findings in the field, while leaving room for new explanatory variables such as labour productivity, wages and foreign output in a theoretically plausible manner.

The importance of the industrial sector in Mexico stems from its contribution to output, employment and exports. In 2015, the industrial sector accounted for 33.2\% of gross domestic product (GDP), 39.2\% of total employment and $91.6 \%$ of total goods exports. Given that Mexico's industrial sector depends heavily on imported intermediate inputs, capital stock and technology, there is a strong link between exchange-rate depreciation and rising consumer goods prices (i.e. consumer goods inflation). Moreover, the reference point for choosing the study interval was the implementation of the inflation-targeting system in Mexico in January 2001. Under the inflation-targeting framework, the central bank is publicly committed to achieving a specific rate of inflation, with the more fundamental mission of providing price stability. In furtherance of this goal, the central bank is independent of the federal government and enjoys considerable discretion in the formulation and implementation of monetary policy measures. Another important feature of an inflation-targeting central bank is the obligation to meet high standards of transparency and accountability, mainly regarding the ends and means of monetary policy.

By the same token, to guarantee the central bank's credibility and the effectiveness of monetary policy, it is necessary not only to set feasible targets and realistic margins of error, ${ }^{2}$ but also to periodically generate econometric studies on the determinants of price instability and output fluctuations. These empirical studies must also address problems such as the changing responsiveness of key variables to economic policy actions (e.g., the response of industrial output and consumer goods prices to an interest rate increase of a certain magnitude). Although this paper focuses on long-term econometric analysis using a VEC model, some attention is given to short-term dynamics as well. This approach, in conjunction with the set of variables included in the model, allows us to: (i) identify several empirical relationships consistent with economic theory and with some salient aspects of previous research; and (ii) offer some new insights into the behaviour of consumer goods prices and industrial output. Among other contributions, this paper shows that in the long run: (i) wage increases and exchange-rate depreciation give rise to cost-push inflation, as they raise consumer goods prices and lower industrial production; and (ii) a more productive workforce can play a major role not only in stimulating industrial production but also in stabilizing consumer goods prices. Macklem and Yetman (2001) show that, for the United States and Canada, the productivity growth rate influences the behaviour of prices, conceivably by changing the relationship between output and inflation. Thus, an important contribution of this paper is to show that, in a developing economy such as Mexico, higher labour productivity can be a significant factor not only in stimulating industrial output, but also in stabilizing consumer goods prices.

This study is organized as follows. Section II offers a brief review of the empirical literature on the topic. Section III develops the theoretical model. Section IV focuses on data management, econometric methodology and the presentation of empirical evidence. Lastly, section $\vee$ concludes by interpreting the empirical evidence and their economic policy implications.

\footnotetext{
2 Since January 2003, the Bank of Mexico's official target for the annual rate of inflation has been 3\%, with a range of $+/-1$ percentage point.
} 


\section{Literature review}

A number of recent empirical papers have been devoted to analysing the determinants of inflation in Mexico and other Latin American countries, but only a small portion of these studies address the causes of output changes as well. Using a three-variable vector autoregression (VAR) model that includes the real budget deficit, real exchange rate and inflation, Dornbusch, Sturzenegger and Wolf (1990) provide empirical evidence on the responsiveness of inflation to fiscal and exchange-rate shocks in five Latin American economies: Argentina, Brazil, Mexico, Peru and the Plurinational State of Bolivia. These authors show that real exchange-rate depreciation is a major cause of price instability in all the countries except the Plurinational State of Bolivia. Real fiscal expansion, on the other hand, leads to inflation only in Mexico, Peru and the Plurinational State of Bolivia. Lastly, Brazil and Argentina display strong signs of inertial inflation, with prices heavily influenced by their own shocks.

Rogers and Wang (1995) estimate a VAR model for the Mexican economy with five variables (budget deficit, real money supply, real exchange rate, prices and output). They find that inflation is more responsive to fiscal and monetary shocks than to exchange-rate shocks. Moreover, output fluctuations stem from real and fiscal shocks and, to a lesser extent, from monetary and exchange-rate shocks. Thus, they conclude that monetary and exchange-rate policies are relatively ineffective when it comes to encouraging economic activity.

Agénor and Hoffmaister (1997) carried out an empirical study of inflation based on four developing economies, namely Chile, Mexico, the Republic of Korea and Turkey. The authors estimate a VAR model for each country, which indicate that a lax monetary policy leads to inflation. It is worth noting that in Mexico an increase in the money supply had a short-lived effect on output and a persistent effect on prices. Lastly, with the notable exception of the Republic of Korea, currency depreciation is inflationary in all the countries.

Using different econometric methodologies, Catalán and Galindo (2005) prove that there is a positive relationship between inflation and money supply in Mexico, and this finding is consistent across all four monetary aggregates. The evidence provided also supports the notion that output can be stimulated through monetary expansion, but the authors emphasize that the link between money and output is considerably more elusive than the link between money and prices.

Baqueiro, Díaz de León and Torres (2003) estimate the pass-through effect from exchange rates to prices. Using a sample of 16 small open economies (including Mexico) with flexible exchange-rate systems, they show that the pass-through effect weakens as these economies move from a high- to a low-inflation stage. Put differently, the inflationary impact of exchange-rate depreciation weakens as the stabilization process moves forward. In this context, several papers conclude that the Mexican pass-through effect declined from the 1990s to the 2000s (Capistrán, Ibarra and Ramos-Francia, 2012; Cortés, 2013; Guillermo and Rodríguez, 2014; Rodríguez, 2015). In particular, Rodríguez (2015) points out that the pass-through effect became so small after the implementation of inflation targeting in Mexico that sudden exchange-rate depreciations do not significantly change the trajectory of the price level.

The work of Hernández (2015), however, successfully casts doubt on the accuracy of the earlier findings, arguing that both Capistrán, Ibarra and Ramos-Francia (2012) and Cortés (2013) make use of monthly data for the annual growth rate of inflation and exchange-rate depreciation when estimating the VAR model and the accumulated impulse-response functions, thereby creating a mismatch between the frequency of the data and the periodicity of the growth rate of the variables being studied. In Hernández's view, this mismatch ultimately results in a downwardly-biased estimation of price elasticity with respect to the exchange rate.

In a parallel line of research, Carrasco and Ferreiro (2011) analyse the Mexican inflation stabilization process, concluding that the inflation-targeting framework made it easier for the Bank of 
Mexico to bring inflationary expectations under control. In the case of Brazil, Caldas (2013) argues that private agents' inflationary expectations affect their economic decisions, thereby becoming a major source of price instability. Hence, a central bank that credibly targets inflation can reduce the negative impact of macroeconomic stabilization on real variables, mainly by inducing a downward trend in inflationary expectations.

To sum up, the recent empirical literature identifies the following variables as leading sources of inflation: budget deficits, money supply, the exchange rate and inflationary expectations. Furthermore, the econometric literature underlines the following aspects: (i) exchange-rate shocks were a powerful cause of price instability in high-inflation Latin American countries such as Argentina, Brazil and Mexico "in the 1980s" (Dornbusch, Sturzenegger and Wolf, 1990); (ii) more recently, fiscal and monetary expansion has become more inflationary than exchange-rate depreciation (Rogers and Wang, 1995); (iii) the pass-through effect decreases as the macroeconomic stabilization process moves forward (Baqueiro, Díaz de León and Torres, 2003; Capistrán, Ibarra and Ramos-Francia, 2012; Cortés, 2013; Guillermo and Rodríguez, 2014; Rodríguez, 2015); (iv) however, the pass-through effect from the exchange rate to prices, while smaller than before, has probably been underestimated (Hernández, 2015); and (v) inflation-targeting monetary policy has been useful in anchoring inflationary expectations in developing countries such as Brazil and Mexico (Carrasco and Ferreiro, 2011; Caldas, 2013). By the same token, economic activity responds to fiscal and real shocks and, to a lesser degree, to monetary and exchangerate shocks (Rogers and Wang, 1995). Lastly, some authors state that an expansionary monetary policy yields a transitory increase in economic activity and a long-lived and stronger rise in prices (Agénor and Hoffmaister, 1997; Catalán and Galindo, 2005).

\section{An aggregate demand-aggregate supply model}

This section lays the foundation for a VEC model consisting of 10 variables: government spending, money supply, interest rate, exchange rate, wages, labour productivity, capacity utilization, prices, domestic output and foreign output. The recent econometric literature identifies most of these variables as key determinants of macroeconomic fluctuations, whereas the model itself allows new variables to be brought into play, in particular wages and labour productivity. It is very common in empirical economic studies to work with real rather than nominal variables. This paper, however, follows the standard recommendation made by Hoover, Johansen and Juselius (2008) and Juselius (2011, p. 350) in terms of not deflating nominal variables such as the money supply, the interest rate and the exchange rate, in order to "allow the data to speak freely". Adjusting such variables for inflation, according to these authors, can interfere with critical signals in the time series and thus undermine the reliability of the empirical evidence. ${ }^{3}$ Moreover, Hoover, Johansen and Juselius (2008) suggest favouring empirical evidence over ex ante economic theory when working with VEC models, such as the one we estimate hereafter.

\section{The aggregate demand equations}

An open economy version of the IS-LM model is used to obtain the demand-side equations. The model is built upon two standard assumptions: (i) the exchange-rate system is flexible; and (ii) the national economy is small enough for foreign prices to be taken as given. Two behavioural relationships depict the dynamics of aggregate demand, one relating to the goods market and the other to the money market.

\footnotetext{
3 It is also important to consider that Mexican inflation has been relatively low since the implementation of the inflation-targeting monetary policy in 2001.
} 
The long-run equilibrium in the goods market is represented by the open economy version of the IS function:

$$
y_{t}=a_{0}+a_{1} p b_{t}+a_{2} i_{t}+a_{3} q_{t}+a_{4} y_{t}^{*}+\varepsilon_{t}^{y}
$$

where $y_{t}$ is the logarithm of domestic output, $p b_{t}$ the logarithm of a scaled version of the public sector balance, $i_{t}$ the interest rate, $q_{t}$ the logarithm of the exchange rate, $y_{t}^{*}$ the logarithm of foreign output and $\varepsilon_{t}^{y}$ a stochastic error term. The public sector balance is scaled up so that it takes only positive values and can be stated in natural logarithms. This transformation in the public sector balance is illustrated in annex A1.

A conventional IS function makes use of government spending $\left(g_{t}\right)$ rather than the public sector balance $\left(p b_{t}\right)$, and $g_{t}$ has a positive effect on domestic output $\left(y_{t}\right)$. Nonetheless, as annex A2 shows, $g_{t}$ turns out to be trend-stationary, which makes it inappropriate for cointegration analysis. In addition to being integrated of order 1 and thus suitable for cointegration testing, the public sector balance performs better in terms of model residual behaviour than government spending. The expected parameter signs in this modified IS function are: $a_{1}<0, a_{2}<0, a_{3}>0$ and $a_{4}>0$. Put differently, $a_{1}<0$ because a rise in $p b_{t}$ equates to a fiscal contraction (i.e. a reduction in government spending, an increase in public revenues or both), whereas a decline in $p b_{t}$ reflects a fiscal expansion (i.e. an increase in government spending, a fall in public revenues or both).

Tanzi and Zee (1997) argue that both the budget deficit and government spending have been used in empirical work and that there is no conclusive evidence favouring one fiscal policy indicator over the other.

A conventional LM equation depicts the long-term equilibrium in the money market:

$$
m_{t}=b_{0}+b_{1} i_{t}+b_{2} p_{t}+b_{3} y_{t}+\varepsilon_{t}^{m}
$$

where $m_{t}$ is the logarithm of the money supply, $p_{t}$ is the logarithm of the price level and $\varepsilon_{t}^{m}$ is a disturbance term reflecting money demand shocks. Notice that the left-hand side of equation (2) represents the money supply, while the right-hand side represents the behaviour of demand for money. As a result, the expected parameter signs are: $b_{0}>0, b_{1}<0, b_{2}>0$ and $b_{3}>0$.

\section{The aggregate supply equations}

We draw on the seminal paper by Tobin (1972) to specify a wage-price mechanism consisting of a wage-setting equation and a markup equation (or price equation). As will be seen below, the price equation can be thought of as the inverse supply curve of firms insofar as it describes the behaviour of the price level.

$$
\begin{gathered}
w_{t}=c_{0}+c_{1} i_{t}+c_{2} c u_{t}+\varepsilon_{t}^{w} \\
p_{t}=d_{0}+d_{1} w_{t}+d_{2} v_{t}+d_{3} c u_{t}+d_{4} q_{t}+\varepsilon_{t}^{p}
\end{gathered}
$$

Equation (3) is a modified version of the wage-setting equation developed by Tobin (1972). Broadly speaking, Tobin takes the nominal wage growth rate as a function of inflationary expectations and the unemployment rate, which is an indirect measure of labour demand or "a proxy for the level of output compared to capacity" (Blanchard and Fischer, 1990, p. 543). In contrast, our empirical specification states the variables in levels, as opposed to growth rates or first differences, the idea being to work with non-stationary variables so that cointegration analysis can be undertaken. Second, we shall, in 
principle, assume that the Fisher equation ${ }^{4}$ holds, so that inflationary expectations can be captured by the nominal interest rate. In this manner, we can specify nominal wages as an increasing function of the nominal interest rate $\left(i_{t}\right)$. Third, capacity utilization (denoted by $c u_{t}$ ) is used in equation (3) as a proxy for labour demand. According to Blanchard and Fischer (1990, p. 543), econometric equations can include a number of measures that serve this purpose, such as capacity utilization and the output gap. Thus, an improvement in capacity utilization may shift the labour demand curve to the right, thereby bringing down unemployment and raising wages. Accordingly, all the parameters in equation (3) are expected to have a positive sign. Lastly, $\varepsilon_{t}^{w}$ is a stochastic error term reflecting unexpected changes in other wage-related variables such as the degree of labour mobility, the size of the informal sector and the bargaining power of labour vis-à-vis management.

As pointed out earlier, equation (4) is a price-setting equation which can be regarded as the inverse supply curve of firms insofar as it depicts the behaviour of prices. In Tobin's 1972 paper, the rate of change in prices responds to the rate of change in unit labour costs and to the unemployment rate. Our specification differs in at least four respects: (i) the variables are in levels; (ii) unit labour costs are replaced by wages and labour productivity, on the grounds that unit labour costs go down when labour productivity grows faster than wages and vice versa; (iii) capacity utilization is used instead of the unemployment rate; and (iv) prices here are also a function of the exchange rate $\left(q_{t}\right)$. Lastly, $\varepsilon_{t}^{p}$ is an error term reflecting stochastic changes in price-related variables not explicitly considered. Along these lines, prices are assumed to bear a direct relationship to wages, capacity utilization $\left(c u_{t}\right)$ and the exchange rate $\left(q_{t}\right)$. Any of these variables, at a given juncture, could give rise to inflation. For instance, exchange-rate depreciation could raise the local currency cost of imported intermediate inputs, capital goods and technology, thereby generating cost-push inflationary pressure. Meanwhile, higher labour productivity $\left(v_{t}\right)$ reduces inflationary pressure by bringing down unit labour costs, with $d_{2}$ thus being the only parameter in (4) with a negative sign. Hence, the intuition behind equation (4) is that: (i) the interplay between all the explanatory variables has an impact on per-unit production costs; and (ii) firms set prices above per-unit production costs and then meet whatever demand may emerge for their products subject to the capacity utilization constraint.

\section{Empirical analysis}

\section{Data description}

This section contains the short- and long-term econometric analysis. To that end, first the information space of the model, given by the number and specific choice of variables, is outlined. On the basis of the literature review of section I, the theoretical model of section II, the availability of monthly data and a number of empirical tests and estimations, we selected 10 observable variables: public sector balance as a fiscal policy index; money supply; interest rate; exchange rate; wages; labour productivity; capacity utilization; prices; domestic output; and foreign output.

Hoover, Johansen and Juselius (2008) and Juselius (2011, p. 350), among others, point out that adjusting nominal variables for inflation undermines the reliability of the empirical results by distorting the signals embodied in the original time series and preventing those series from speaking freely. Furthermore, Hoover, Johansen and Juselius (2008) argue that, when working with multivariate time series models, empirical evidence must prevail over economic theory and not the other way around. In this context, it must be stressed that: (i) all the variables of the model are seasonally adjusted; (ii) with the exception of

\footnotetext{
${ }_{4}$ The ex ante version of the Fisher equation states that $i_{t}+r_{t}^{e}+\pi_{t}^{e}$, where $r_{t}^{e}$ is the expected real interest rate and $\pi_{t}^{e}$ is the symbol for the expected inflation rate for the period $t$.
} 
the interest rate and capacity utilization, which are measured in percentages, the variables are stated in natural logarithms so that long-run elasticities can be estimated; and (iii) following the standard recommendation of Hoover, Johansen and Juselius (2008) and Juselius (2011), the nominal variables of the model (i.e. the public sector balance, money supply, interest rate, exchange rate and wages) are not adjusted for inflation. All that stated, each variable will now be described in detail:

1. As a fiscal policy index, we decided to use the public sector balance $\left(p b_{t}\right)$, which is the gap between the revenues and expenditures of the federal government, the State-owned enterprises under budgetary control, and the non-budgetary sector. Government spending had to be discarded because it proved to be trend stationary, as we show in annex A2. Lastly, to be able to transform the public sector balance into logarithms, we applied a straightforward escalation procedure so that it would take only positive values (see annex A1). This enabled us to estimate long-term elasticities with no distortionary effect on the econometric results.

2. The monetary base was taken as a measure of money supply $\left(m_{t}\right)$. We opted for this particular variable after comparing its performance with that of all other measures of money supply, mainly in terms of residual behaviour. A plausible explanation for the observed results is that the monetary base is more responsive to monetary policy changes than other measures of money.

3. To represent the interest rate $\left(i_{t}\right)$, the interest rate on 28-day government bonds (CETES) was chosen from a number of alternatives, as it is a good source of information on current conditions in the money market as a whole.

4. The exchange rate $\left(q_{t}\right)$ taken is the interbank exchange rate, given that most currency transactions involving Mexican pesos and United States dollars are carried out at this particular rate.

5. In view of data availability problems and testing results, we opted for the average nominal wage $\left(w_{t}\right)$ earned by all workers affiliated to the Mexican Social Security Institute as a proxy for the cost of labour.

6. Labour productivity $\left(v_{t}\right)$ in the manufacturing sector (the only measure of productivity available on a monthly basis) was included so that the effect of this variable on industrial production and consumer goods prices could be estimated.

7. Percentage capacity utilization $\left(c u_{t}\right)$ in the manufacturing industry was taken as a proxy for labour demand given that, from the statistical standpoint, this variable seemed to work better than any other measure of the output gap.

8. To measure changes in the price level $\left(p_{t}\right)$, we used the core index of consumer goods prices, so we left out energy and food prices to avoid having a biased measure of consumer goods inflation and to improve residual behaviour.

9. The Mexican industrial production index was used to measure domestic output $\left(y_{t}\right)$, given that the focus of this paper is on the long-term determinants of Mexican industrial activity and consumer goods prices.

10. In view of the unavailability of monthly data for United States GDP, we used the United States industrial production index as a proxy for foreign output $\left(y_{t}^{*}\right)$.

The model estimation is based on monthly data from the National Institute of Statistics and Geography (INEGI) and the Bank of Mexico for each variable from December 2001 to May 2016 (174 observations for each variable in all). As we explain below, the sample span is one of three decision variables used to properly adjust the model. This sample period works fairly well with the information space and lag structure of the model. An important aspect to consider in this regard is that, as of January 2007, the National Institute of Statistics and Geography (INEGI) of Mexico broadened the coverage of the statistical 
data for the manufacturing sector. The result is that the new time series for percentage capacity utilization $\left(c u_{t}\right)$ and labour productivity $\left(v_{t}\right)$ comprise 240 types of economic activity (as opposed to 205 types in the old time series) based on the North American Industry Classification System (United States Census Bureau, 2007). Nonetheless, we were able to apply a simple data chaining technique, known as retropolation, in view of three facts: (i) the old and new times series are closely related; (ii) they are measured at the same frequency; and (iii) they overlap over the period 2007-2008. Put briefly, the new time series were extended backward in levels by replicating the growth path of the old time series. Through this procedure, the data for capacity utilization and labour productivity became a mixture of two components: (i) the actual measure of each variable in the recent period (January 2007-May 2016); and (ii) a suitable proxy for each variable in the previous period (December 2001-December 2006). Most importantly, longer historical series for capacity utilization and labour productivity resulted not only in a more statistically appropriate model, but also in more reliable cointegration tests.

\section{Breakpoint unit root and stationarity tests}

This section aims to identify the long-term equilibrium relationships between the model variables. The first step in doing so is to establish the order of integration of the variables by means of two types of tests: augmented Dickey-Fuller (ADF) tests with structural breaks, and Kwiatkowski and others (1992) stationarity tests. Following Hamilton's (1994, p. 501) methodology, the test equation for each variable is specified so as to capture the behaviour of the time series under the null and alternative hypotheses. The breakpoint ADF tests have three characteristics. First, the break date is estimated from each time series. Second, 4 out of the 10 variables do not include a linear trend, so in these four cases structural changes can only take the form of a shift in the intercept of the test equation. Third, in the case of trending variables, two other possibilities were considered under the alternative hypothesis: (i) a change in the trend and (ii) a simultaneous change in the trend and the intercept. For simplicity, the test results reported here are for an intercept break alone (see table 1). ${ }^{5}$

The breakpoint unit root and stationarity tests are consistent in indicating that the following seven variables are integrated of order $1(I(1))$ in levels: public sector balance $\left(p b_{t}\right)$, money supply $\left(m_{t}\right)$, exchange rate $\left(q_{t}\right)$, labour productivity $\left(v_{t}\right)$, capacity utilization $\left(c u_{t}\right)$, domestic output $\left(y_{t}\right)$ and foreign output $\left(y_{t}^{*}\right)$. However, it is not uncommon for unit root and stationarity tests to yield contradictory outcomes, just as happens with the other three variables, namely the interest rate $\left(i_{t}\right)$, prices $\left(p_{t}\right)$ and wages $\left(w_{t}\right)$. In the case of prices and the interest rate, our conclusion is that both variables are I(1) on the following grounds:

1. Previous empirical evidence for Mexico suggests that the price level has been I(1) and that the inflation rate (i.e. the rate of change in the price level) has been stationary at least since late 2000 or early 2001 (Chiquiar, Noriega and Ramos-Francia, 2010, p. 4; Noriega and Ramos-Francia, 2009, pp. 9-14). For its part, the interest rate has been as volatile as the exchange rate and more volatile than any of the monetary aggregates (Torres, 2000, p. 15). We use a normalized and unbiased measure of dispersion, known as a variation coefficient, ${ }^{6}$ to show that the interest rate $\left(i_{t}\right)$ was also much more volatile than the inflation rate and the price level $\left(p_{t}\right)$ over the reference period. The estimated variation coefficients (EVCs) for the interest rate, the inflation rate and the price level are $0.35,0.21$ and 0.04 , respectively.

\footnotetext{
5 The unit root tests applied also take account of the fact that structural breaks can occur suddenly or gradually. Additive outliers reflect sudden breaks, whereas innovation outliers reflect gradual breaks. Additive outliers were used in the specific cases of the interest rate, exchange rate, wages, capacity utilization and output, given that these variables underwent radical shifts at some point over the reference period. In the other cases, unit root tests were carried out with innovation outliers.

6 The estimated variation coefficient (EVC) for a given variable, say $Y$, is obtained as follows: EVC $=(S / \bar{Y})(1+1 / 4 T)$, where $S$ is the sample standard deviation of $Y, \bar{Y}$ is the sample average of $Y$, and $T$ is the sample size. Therefore, $(1+1 / 4 T)$ is the small sample bias correction factor proposed by Rohlf and Sokal (1995). Accordingly, for a sample of size $T$ we get an unbiased and normalized measure of dispersion.
} 
Table 1

Unit root tests with structural breaks and stationarity tests, December 2001-May 2016

\begin{tabular}{|c|c|c|c|c|}
\hline Variable & $\begin{array}{l}\text { Specification of the } \\
\text { test equation }\end{array}$ & $\begin{array}{l}\text { ADF breakpoint unit root } \\
\text { test statistic }\left(\mathrm{H}_{0} \text { : unit root) }\right.\end{array}$ & $\begin{array}{l}\text { KPSS test statistic } \\
\left(\mathrm{H}_{0} \text { : stationarity) }\right.\end{array}$ & Order of Integration \\
\hline$p b_{t}$ & $C$ & -3.27 & $1.11^{\star \star \star}$ & 1 \\
\hline$\Delta p b_{t}$ & C & $-12.72^{\star \star \star}$ & 0.15 & 0 \\
\hline$m_{t}$ & $\mathrm{C}$ and $\mathrm{T}$ & -3.31 & $0.25^{\star \star \star}$ & 1 \\
\hline$\Delta m_{t}$ & C & $-8.89^{\star \star \star}$ & 0.08 & 0 \\
\hline$i_{t}$ & C & -4.16 & $1.4^{\star \star \star}$ & $\geq 1$ \\
\hline$\Delta i_{t}$ & C & $-6.21^{\star \star \star}$ & $0.37^{\star}$ & $?$ \\
\hline$\Delta^{2} i_{t}$ & $\mathrm{C}$ & $-7.52^{* \star *}$ & 0.16 & 0 \\
\hline$q_{t}$ & $\mathrm{C}$ and $\mathrm{T}$ & -4.07 & $0.18^{\star \star}$ & 1 \\
\hline$\Delta q_{t}$ & C & $-11.86^{\star \star \star}$ & 0.07 & 0 \\
\hline$w_{t}$ & $\mathrm{C}$ and $\mathrm{T}$ & -1.83 & $0.43^{\text {** }}$ & $\geq 1$ \\
\hline$\Delta w_{t}$ & C & $-21.03^{\star \star \star}$ & $1.71^{\star \star \star}$ & $?$ \\
\hline$\Delta^{2} w_{t}$ & C & $-14.5^{\star \star \star}$ & 0.18 & 0 \\
\hline$v_{t}$ & $\mathrm{C}$ and $\mathrm{T}$ & -2.92 & $0.22^{\star * *}$ & 1 \\
\hline$\Delta v_{t}$ & C & $-14.82^{* * *}$ & 0.34 & 0 \\
\hline$c u_{t}$ & $\mathrm{C}$ & -3.12 & $0.81^{* \star *}$ & 1 \\
\hline$\Delta c u_{t}$ & C & $-14.74^{\star \star \star}$ & 0.04 & 0 \\
\hline$p_{t}$ & $\mathrm{C}$ and $\mathrm{T}$ & -3.66 & $0.32^{* \star *}$ & $\geq 1$ \\
\hline$\Delta p_{t}$ & C & $-4.28^{\star}$ & $0.65^{\star \star}$ & $?$ \\
\hline$\Delta^{2} p_{t}$ & C & $-16.21^{* \star \star}$ & 0.04 & 0 \\
\hline$y_{t}$ & $\mathrm{C}$ and $\mathrm{T}$ & -4.0 & $0.12^{*}$ & 1 \\
\hline$\Delta y_{t}$ & C & $-7.32^{\star \star \star}$ & 0.07 & 0 \\
\hline$y_{t}^{*}$ & C & -3.65 & $0.54^{\star *}$ & 1 \\
\hline$\Delta y_{t}^{*}$ & C & $-6.98^{\star \star *}$ & 0.07 & 0 \\
\hline
\end{tabular}

Source: Prepared by the authors, on the basis of data from the National Institute of Statistics and Geography (INEGI) and the Bank of Mexico.

Note: C stands for constant and T for trend. The symbols and are the first and second difference operators, respectively. The asterisks ${ }^{*},{ }^{* *}$ and ${ }^{* * *}$ denote rejection of the null hypothesis at the $10 \%, 5 \%$ and $1 \%$ significance levels, respectively. The ADF breakpoint unit root test results rely on Vogelsang (1993) asymptotic one-sided p-values. The lag length of the test equation is determined by means of the Akaike information criterion. The break type reported here is a level shift, but other possibilities were explored. The break date is estimated from the time series to maximize the likelihood of the unit root null hypothesis being rejected. The KPSS (Kwiatkowski-Phillips-Schmidt-Shin) test results are based on the critical values proposed by Kwiatkowski and others (1992). The Newey-West bandwidth selection method and the Bartlett kernel are used to control the bandwidth.

2. Esquivel and Razo (2003, p. 189), using monthly data for the Mexican economy from January 1989 to October 2000, conclude that both the interest rate on 28-day government bonds (CETES) and the consumer price index are I(1). Using monthly data for the period January 1994-October 2006, Cavazos and Rivas-Aceves (2009, pp. 118-119) reach the same conclusion, meaning that both the interest rate and the price level in Mexico are I(1). Lastly, Garcés (2008, p. 688) shows the same thing, but with quarterly data for the period 1980-2000.

3. A replication of the tests with a larger sample (January 1994-May 2016) leads to the conclusion that both the interest rate and prices are I(1) in levels.

The data available for nominal wages are not sufficient to carry out breakpoint unit root and stationarity tests with larger samples, but this variable is also likely to be I(1) given that: (i) the unit root tests used here consistently point to this conclusion under different scenarios of structural change; (ii) other unit root tests, such as the Phillips-Perron and augmented Dickey-Fuller tests, produce results 
in line with those of the breakpoint unit root tests; and (iii) other measures of wages indicate that this variable has exhibited the same order of integration as prices and the money supply since the last decade (i.e. has been I(1)). Thus, it is reasonable to conclude that all the variables of the model are I(1) in levels.

\section{Johansen cointegration tests}

To identify the long-term equilibrium relationships among the variables at hand, Johansen cointegration tests must be implemented (Johansen, 1995; Juselius, 2007). The first step in performing these tests is to estimate an unrestricted vector autoregression (VAR) model that is statistically appropriate. Three decision variables were utilized to improve residual behaviour as much as possible: the information space, the lag length and the time interval. It has already been explained that the information space of the model consists of the 10 non-stationary variables previously detailed and that the sample period runs from December 2001 to May 2016. As for the lag structure of the VAR model, we chose six lags for each variable in each equation. The model is represented by equation (5):

$$
Y_{t}=A_{1} Y_{t-1}+A_{2} Y_{t-2}+, \ldots,+A_{p} Y_{t-p}+\psi X_{t}+\eta_{t}
$$

where $Y_{t}=\left[p b_{t}, m_{t^{\prime}} i_{t}, q_{t^{\prime}}, w_{t^{\prime}} v_{t^{\prime}} c u_{t}, p_{t^{\prime}} y_{t^{\prime}} y_{t}^{*}\right]^{\prime}$ is a $10 \times 1$ vector of endogenous variables and $X_{t}$ is a $2 \times 1$ vector of deterministic regressors that includes a 1 and a time trend, denoted $t$. The 1 is to designate the constant term in each equation, while the time trend, $t$, is to take account of the fact that some variables tend to grow over time. Moreover, $\eta_{t}$ stands for a $10 \times 1$ vector of innovations, $A_{i}$ is a $10 \times 10$ coefficient matrix with $i=1,2, \ldots, 6, \Psi$ is a $10 \times 2$ coefficient matrix, and the value of subscript $p$, denoting the lag length of the model, is equal to 6.

The first step in evaluating the statistical properties of this model is to carry out the multivariate serial correlation Lagrange multiplier $(L M)$ tests. According to the $L M$ statistics and probability values (p-values) reported in table 2, the null hypothesis of no serial correlation is not rejected at either the $5 \%$ or the $10 \%$ significance level up to lag order 10.

Table 2

Multivariate serial correlation Lagrange multiplier tests, December 2001-May 2016

\begin{tabular}{ccc}
\hline Lag order $p$ & Lagrange multiplier statistics & Probability $^{\mathrm{a}}$ \\
\hline 1 & 103.3748 & 0.3886 \\
\hline 2 & 96.36808 & 0.5842 \\
\hline 3 & 116.3448 & 0.1262 \\
\hline 4 & 77.56845 & 0.9530 \\
\hline 5 & 117.0113 & 0.1176 \\
\hline 6 & 113.1726 & 0.1736 \\
\hline 7 & 91.04501 & 0.7276 \\
\hline 8 & 113.6089 & 0.1664 \\
\hline 9 & 82.93674 & 0.8916 \\
\hline 10 & 99.76945 & 0.4877
\end{tabular}

Source: Prepared by the authors, on the basis of data from the National Institute of Statistics and Geography (INEGI) and the Bank of Mexico.

a $H_{0:}$ there is no serial correlation at lag order $p$. Probabilities from chi-square distribution with 81 degrees of freedom. 
Next, the White heteroskedasticity test in its multivariate version is performed. According to the joint test result shown in table 3, the null hypothesis of homoskedasticity cannot be rejected at either the $5 \%$ or the $10 \%$ level. Thus, it is reasonable to conclude that, by and large, VAR residuals are free of serial correlation and heteroskedasticity.

Table 3

White heteroskedasticity test for VAR residuals, December 2001-May 2016

\begin{tabular}{ccc}
\hline Chi-square statistic $\left(x^{2}\right)$ & Degrees of freedom & Probability $^{\mathrm{a}}$ \\
\hline 6713.739 & 6655 & 0.3038 \\
\hline
\end{tabular}

Source: Prepared by the authors, on the basis of data from the National Institute of Statistics and Geography (INEGI) and the Bank of Mexico.

a $H_{0}$ : homoskedasticity. This result is for the joint test, which is performed in levels and squares only (no cross terms are included).

Due to volatility episodes, mostly during the years of the global economic crisis, VAR residuals depart from normality. Although the use of dummy variables of the 0,1 form to account for outliers (stemming from these episodes of volatility) could be acceptable in this case (Patterson, 2000, p. 616; Clements and Mizon, 1991), this option did not yield the expected results. In these circumstances, it is worth recalling that while residual normality is necessary for a clear-cut application of the maximum likelihood (ML) theory to the identification and estimation of cointegrating vectors (Mackinnon, Haug and Michelis, 1999, p. 563), it is somewhat restrictive in empirical work (Cheung and Lai, 1993, p. 314). In this context, Gonzalo (1994) shows that the ML estimators used in cointegration analysis yield asymptotically valid inferences even when the normality assumption does not hold, whereas Johansen (1995, p. 20) relaxes the requirement of residual multivariate normality to perform cointegration tests.

The next step is to rewrite equation (5), representing an unrestricted VAR model, as a VEC model. This is necessary to carry out Johansen's cointegration tests:

$$
\Delta Y_{t}=\Pi Y_{t-1}+\Gamma_{1} \Delta Y_{t-1}+\Gamma_{2} \Delta Y_{t-2}+, \ldots, \Gamma_{(p-1)} \Delta Y_{t-(p-1)}+\psi X_{t}+\eta_{t}
$$

where $\Pi=\sum_{i=1}^{p} A_{i}-I, \Gamma_{i}=-\sum_{j=i+1}^{p} A_{j}$, and $\eta_{t}$ is an i.i.d. vector of innovations with mean zero and variance $\Omega$. As can be seen, a $p$ order VAR model gives rise to a $(p-1)$ VEC model, so cointegration tests are undertaken under a five-lag VEC model. The underlying foundation of the multivariate cointegration tests is the Granger representation theorem (Engle and Granger, 1987). The fourth implication of this theorem assumes that: (i) the variables of a $k$-dimensional vector are all I(1); and (ii) the rank of coefficient matrix $\Pi$ is reduced (i.e. $r<k$, where $r$ stands for the rank of $\Pi$ and $k$ for the dimension of $\Pi$, which is equal to the number of variables in the model). If those two assumptions are satisfied, it can be asserted that coefficient matrices $\alpha$ and $\beta$ (both with dimension $k x r$ and rank $r$ ) do exist and are such that: (i) $\Pi=\alpha \beta^{\prime}$; and (ii) $\beta^{\prime} Y_{t-1}$ is a stationary system. Therefore, equation (6) can be reformulated as:

$$
\Delta Y_{t}=\alpha \beta^{\prime} Y_{t-1}+\Gamma_{1} \Delta Y_{t-1}+\Gamma_{2} \Delta Y_{t-2}+, \ldots, \Gamma_{(p-1)} \Delta Y_{t-(p-1)}+\psi X_{t}+\eta_{t}
$$

where $\beta$ is a long-run coefficient matrix and $\beta^{\prime} Y_{t-1}$ is an $r \times 1$ stationary system. Moreover, $\alpha$ is a matrix of adjustment coefficients that, along with coefficient matrices $\Gamma_{1}, \Gamma_{2}, \ldots, \Gamma_{(p-1)}$, describes the short-term dynamic responses following a shock (i.e. an unexpected change in one of the elements of vector $\eta_{t}$ ).

To conduct Johansen's cointegration tests on the basis of equation (7), an intercept term is included in the cointegrating space so that the long-term economic relationships are not forced through the origin (Patterson, 2000, p. 625). The data space is given by the VAR model and is allowed to have 
a time trend because most of the variables, when stated in levels, incorporate a constant and a linear trend. By the same token, Johansen cointegration tests consist of two different sorts of likelihood ratio (LR) tests: the trace test, whose statistics are represented by $\lambda_{\text {trace}}$; and the maximum eigenvalue test, whose statistics are denoted by $\lambda_{\max }$.

At the $5 \%$ significance level, trace tests indicate that there are four cointegrating relationships, while maximum eigenvalue tests point to the conclusion that there are only three. When trace and maximum eigenvalue tests yield inconsistent results, Johansen's (1995) advice is to solve the contradiction by choosing the number of cointegrating equations that yields the most plausible economic interpretation. Another important consideration is that maximum eigenvalue tests are more powerful than trace tests (Patterson, 2000, pp. 620-621). Several normalizations of the cointegrating vectors were conducted, and the conclusion was that three of them were consistent with economic theory, which is in agreement with the results of the maximum eigenvalue tests. For the sake of brevity, we only present the results of the maximum eigenvalue tests (see table 4 ). ${ }^{7}$

Table 4

Johansen maximum eigenvalue tests for cointegration, December 2001-May 2016

\begin{tabular}{ccccc}
\hline Null hypothesis & Alternative hypothesis & $\lambda_{t \max }$-statistic & $5 \%$ critical value & Probability \\
\hline$r=0^{*}$ & $r=1$ & 114.8932 & 64.50472 & 0.0000 \\
\hline$r \leq 1^{*}$ & $r=2$ & 78.31435 & 58.43354 & 0.0002 \\
\hline$r \leq 2^{*}$ & $r=3$ & 57.33698 & 52.36261 & 0.0143 \\
\hline$r \leq 3$ & $r=4$ & 44.55066 & 46.23142 & 0.0750 \\
\hline$r \leq 4$ & $r=5$ & 24.82795 & 40.07757 & 0.7781 \\
\hline$r \leq 5$ & $r=6$ & 18.68832 & 33.87687 & 0.8405 \\
\hline$r \leq 6$ & $r=7$ & 15.41935 & 27.58434 & 0.7144 \\
\hline$r \leq 7$ & $r=8$ & 12.71395 & 21.13162 & 0.4789 \\
\hline$r \leq 8$ & $r=9$ & 9.951978 & 14.26460 & 0.2151 \\
\hline$r \leq 9$ & $r=10$ & 0.289676 & 3.841466 & 0.5904
\end{tabular}

Source: Prepared by the authors, on the basis of data from the National Institute of Statistics and Geography (INEGI) and the Bank of Mexico.

Note: The letter $r$ stands for the number of cointegrating equations. The lag length of the VEC model is 5. A constant in the cointegrating space and a linear trend in the data space are included, with MacKinnon and others (1999) p-values being utilized. Maximum eigenvalue tests indicate the existence of 3 cointegrating equations at the 5\% significance level. An asterisk * denotes rejection of the null hypothesis at the $5 \%$ significance level.

\section{The long-term equations}

Concerning equations (6) and (7) and table 4, it is worth noting that the matrix $\Pi\left(=\alpha \beta^{\prime}\right)$ lacks a unique identification. This means that there are a number of combinations of $\alpha$ and $\beta$ ' that can give rise to $\Pi$ and that economic theory must play a leading role in identifying not only the number, as has just been done, but also the form of the cointegrating equations. To depict the long-run economic relationships in a VEC framework, we must recall that the expression $\beta^{\prime} Y_{t-1}$ of equation (7) is a stationary system or a vector of error correction terms (ECT). Formally, $\beta^{\prime} Y_{t-1}=\left[E C T 1_{t-1}, E C T 2_{t-1}, E C T 3_{t-1}\right]^{\prime}$ where $E C T 1_{t-1}$ has been normalized for consumer goods prices, ECT $2_{t-1}$ for industrial production and $E C T 3_{t-1}$ for the public sector balance. Table 5 displays the estimates of these three cointegrating vectors.

\footnotetext{
7 The results of the trace tests are available upon request.
} 
Table 5

Maximum likelihood estimates of cointegrating vectors ( $\beta$ matrix), December 2001-May 2016

\begin{tabular}{|c|c|c|c|}
\hline Variable & $E C T 1_{t-1}$ & $E C T 2_{t-1}$ & $E C T 3_{t-1}$ \\
\hline$p_{t-1}$ & -1 & 0 & 0 \\
\hline$y_{t-1}$ & 0 & -1 & 0 \\
\hline$p b_{t-1}$ & 0 & 0 & -1 \\
\hline$c u_{t-1}$ & $0.08^{\star * \star}$ & $0.01^{\star \star \star}$ & $0.15^{\star}$ \\
\hline$m_{t-1}$ & $1.74^{\star \star \star}$ & $0.28^{\star \star \star}$ & 1.36 \\
\hline$i_{t-1}$ & $-0.02^{\star \star \star}$ & -0.0002 & -0.01 \\
\hline$q_{t-1}$ & $0.28^{\star \star \star}$ & $-0.14^{\star \star \star}$ & -0.16 \\
\hline$w_{t-1}$ & $6.55^{\star \star \star}$ & $-0.48^{\star \star \star}$ & -3.18 \\
\hline$v_{t-1}$ & $-5.93^{\star \star \star}$ & $0.28^{\star \star}$ & -5.93 \\
\hline$y_{t-1}^{*}$ & $-0.52^{\star * *}$ & $0.30^{\star \star *}$ & 1.09 \\
\hline Intercepts & 26.55 & -1.17 & 12.57 \\
\hline
\end{tabular}

Source: Prepared by the authors, on the basis of data from the National Institute of Statistics and Geography (INEGI) and the Bank of Mexico.

Note: Significance levels for the intercept terms are not available. Asterisks *, ${ }^{\star \star}$, and ${ }^{* \star \star}$ indicate that the long-term parameter estimate is statistically significant at the $10 \%, 5 \%$ and $1 \%$ levels, respectively.

In the long run, $E C T 1_{t-1}, E C T 2_{t-1}$ and $E C T 3_{t-1}$ are all equal to zero (i.e. long-run equilibria hold), and these three error correction terms can be restated as long-term equations for prices, output and the public sector balance, respectively.

Parameter estimates should be regarded as long-term elasticities in view of the fact that all variables are stated in natural logarithms, with the exception of $i_{t-1}$ and $c u_{t-1}$, which are measured in percentages. In the case of these two variables, the estimated coefficients should be viewed as semi-elasticities. All the parameter estimates that are statistically significant yield a reasonable economic interpretation. Table 5 shows that in the long term:

1. Higher capacity utilization $\left(c u_{t-1}\right)$ raises consumer goods prices and industrial output, which is consistent with the notion of demand-pull inflation. Moreover, capacity utilization bears a positive relationship to the scaled version of the public sector balance $\left(p b_{t-1}\right)$. It may be recalled that a straightforward escalation procedure was used, so that the public sector balance took only positive values that could then be transformed into natural logarithms. Annex $\mathrm{A} 1$ shows the behaviour of these transformed variables (i.e. the behaviour of $p b_{t-1}$ ) in millions of pesos at current prices and in natural logarithms. The transmission mechanism is taken to work as follows: higher economic activity (i.e. higher capacity utilization) strengthens government revenues, thereby increasing the scaled version of the public sector balance. In the original non-scaled version of the public balance, government revenues increase and the budget deficit diminishes (or the budget surplus increases). Conversely, lower economic activity (i.e. lower capacity utilization) weakens government revenues, thereby driving down $p b_{t-1}$. In the original non-scaled version of the public balance, government revenues fall and the budget deficit increases (or the budget surplus diminishes).

2. Monetary expansion (i.e. an increase in $m_{t-1}$ ) has a positive impact on both industrial output and prices, suggesting that money is not neutral.

3. Interest rates seem to be an effective tool for maintaining price stability, given that the interest rate on 28-day government bonds (CETES) displays a negative relationship with consumer goods prices. 
4. Both exchange-rate depreciation and wage increases represent a source of cost-push inflation. As is well known, exchange-rate depreciation raises the local currency cost of imported intermediate inputs, capital stock and technology, which in turn accelerates consumer goods inflation while depressing industrial output. All else being equal, rising wages tend to put pressure on per-unit production costs, producing a similar effect on prices and production.

5. Higher labour productivity lowers consumer goods prices and stimulates industrial production. Macklem and Yetman (2001) find this to be the case for the United States and Canada and explain that productivity growth stabilizes the price level by improving the relationship between economic activity and inflation. $E C T 1_{t-1}$ and $E C T 2_{t-1}$ in table 5 provide evidence for the important long-term role that labour productivity can play in Mexico. As will be seen, this particular finding suggests that a more qualified and productive workforce can make a definite contribution to the task of ensuring price stability, as well as raising output.

6. United States industrial production has a bearing not only on Mexican industrial production but also on consumer goods prices. $E C T 1_{t-1}$ and $E C T 2_{t-1}$ indicate that increased industrial activity in the United States lessens inflationary pressures in Mexico, in addition to encouraging industrial production.

When a shock occurs, the variables in , $E C T 1_{t-1}, E C T 2_{t-1}$ and $E C T 3_{t-3}$ depart from their cointegrating relationships, i.e. from their long-run equilibria. This departure is assumed to be transitory, however, given the adjustment process that comes into play through coefficient matrix $\alpha$, which in this particular case is a matrix of dimension $10 \times 3$ (see table 6).

Table 6

Matrix of estimated adjustment coefficients ( $\alpha$ matrix), December 2001-May 2016

\begin{tabular}{|c|c|c|c|}
\hline Equation & $E C T 1_{t-1}$ & $E C T 2_{t-1}$ & $E C T 3_{t-1}$ \\
\hline$\Delta p_{t}$ & $-0.01^{\star \star \star}$ & $0.06^{\star \star \star}$ & -0.00001 \\
\hline$\Delta y_{t}$ & $-0.05^{\star \star \star}$ & $-0.33^{\star \star \star}$ & -0.00002 \\
\hline$\Delta p b_{t}$ & 0.39 & -1.85 & $-2.06^{* * *}$ \\
\hline$\Delta c u_{t}$ & 1.49 & $21.07^{*}$ & 0.37 \\
\hline$\Delta m_{t}$ & $-0.07^{\star \star}$ & $0.40^{*}$ & -0.004 \\
\hline$\Delta i_{t}$ & 0.30 & 7.66 & -0.004 \\
\hline$\Delta q_{t}$ & -0.06 & $-0.95^{\star \star}$ & 0.01 \\
\hline$\Delta w_{t}$ & $0.01^{\star *}$ & -0.02 & 0.0003 \\
\hline$\Delta v_{t}$ & $-0.08^{\star \star \star}$ & $0.59^{\star \star \star}$ & 0.005 \\
\hline$\Delta y_{t}^{*}$ & $0.06^{\star \star \star}$ & 0.13 & $0.004^{*}$ \\
\hline
\end{tabular}

Source: Prepared by the authors, on the basis of data from the National Institute of Statistics and Geography (INEGI) and the Bank of Mexico.

Note: Asterisks *, ${ }^{* *}$, and ${ }^{\star * \star}$ indicate that the parameter estimate is statistically significant at the $10 \%, 5 \%$ and $1 \%$ levels, respectively.

Broadly speaking, the picture emerging from table 6 is that every variable adjusts to some kind of long-run equilibrium after a shock, except for the interest rate $\left(i_{t}\right)$. Therefore, this particular variable should be treated as weakly exogenous for the relevant parameters $\alpha$ and $\beta$. The weak exogeneity of the interest rate is due to the fact that all the estimated adjustment coefficients in matrix $\alpha$ lack statistical significance, which means that this variable is unaffected by lagged disequilibria (i.e. by deviations from $\left.\beta^{\prime} Y_{t-1}\right)$. Another implication is that, under the Johansen standard methodology, this variable is still part of the cointegrating equations but cannot be part of the impulse-response analysis, which is undertaken on the basis of a partial system (Johansen, 1995; Patterson, 2000, pp. 674-676). 


\section{Short-term sensitivity analysis}

The next step is to estimate the short-term dynamic responses of consumer goods prices and industrial output to unexpected changes in the variables of the VEC model. This task is undertaken through a set of VEC model orthogonal impulse responses with 95\% confidence intervals. Impulse responses and confidence intervals are estimated by way of the bootstrap replication method developed by Hall (1992). We present only those impulse response functions (IRFs) that are meaningful from a theoretical standpoint and that achieve statistical significance at some point over a 12-month horizon. Figures 1 and 2 depict the effect of a United States industrial production shock on Mexican industrial production and prices, respectively. A shock to a given variable should be regarded as an unexpected one-standard deviation increase lasting only one month. Thus, it can be seen that a United States industrial production shock raises Mexican industrial production between the first and the fifth month and between the ninth and the eleventh month, and that it tends to lower the price level around the first, third and fifth months. The IRFs achieve statistical significance during those periods. Moreover, figure 3 shows that exchange-rate depreciation (i.e. a shock to the exchange rate) puts pressure on the price level around the second month, whereas figure 4 shows that a wage increase has a small but positive impact on prices around the second and the fourth months. Lastly, according to figure 5, a capacity utilization shock yields an inflationary effect around the fourth month. In summary, all these IRFs are consistent with the cointegrating equations.

\section{Figure 1}

Response of industrial production in Mexico to a shock in United States industrial production (Percentage points over a 12-month horizon)

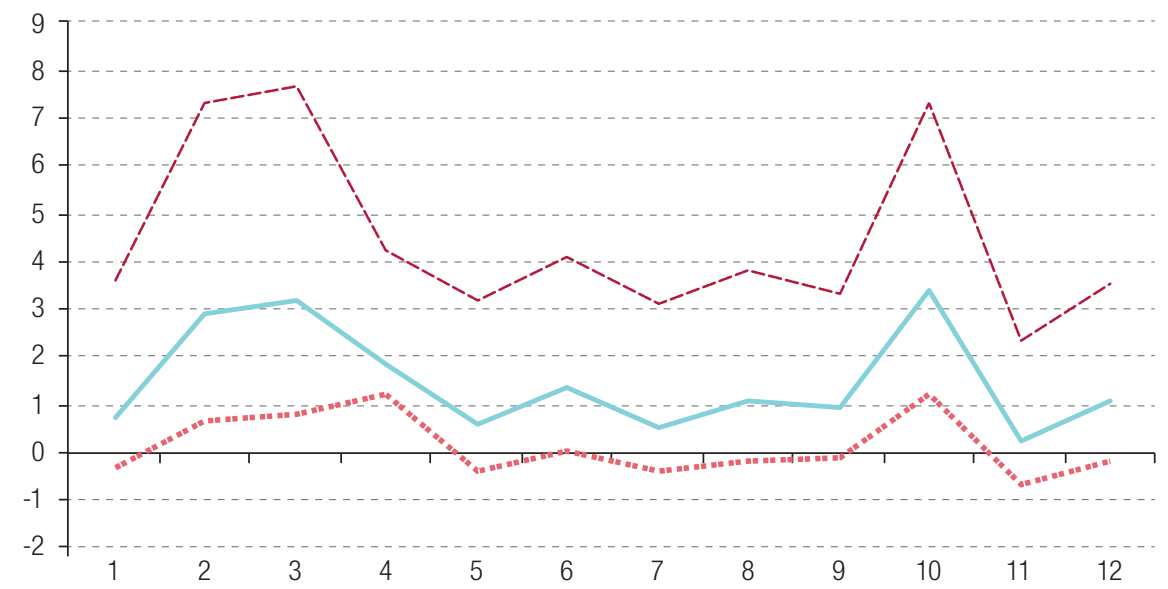

Source: Prepared by the authors, on the basis of data from the National Institute of Statistics and Geography (INEGI) and the Bank of Mexico.

Note: The dotted lines denote a 95\% confidence interval. 


\section{Figure 2}

Response of prices to a shock in United States industrial production

(Percentage points over a 12-month horizon)

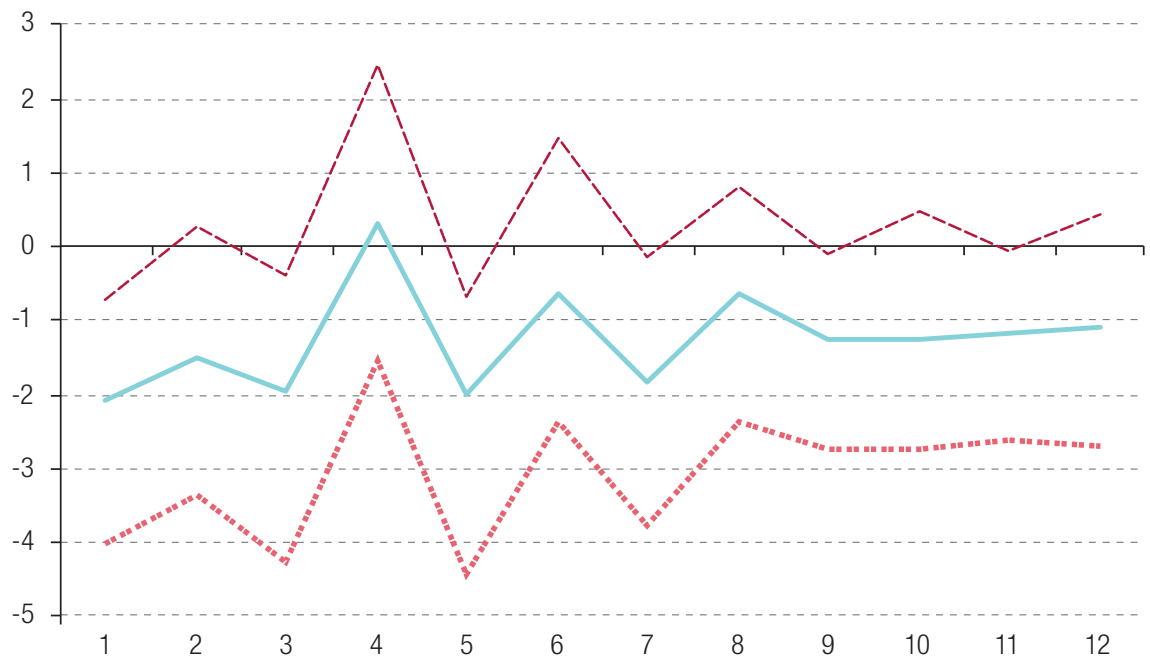

Source: Prepared by the authors, on the basis of data from the National Institute of Statistics and Geography (INEGI) and the Bank of Mexico.

Note: The dotted lines denote a 95\% confidence interval.

Figure 3

Response of prices to exchange-rate depreciation (Percentage points over a 12-month horizon)

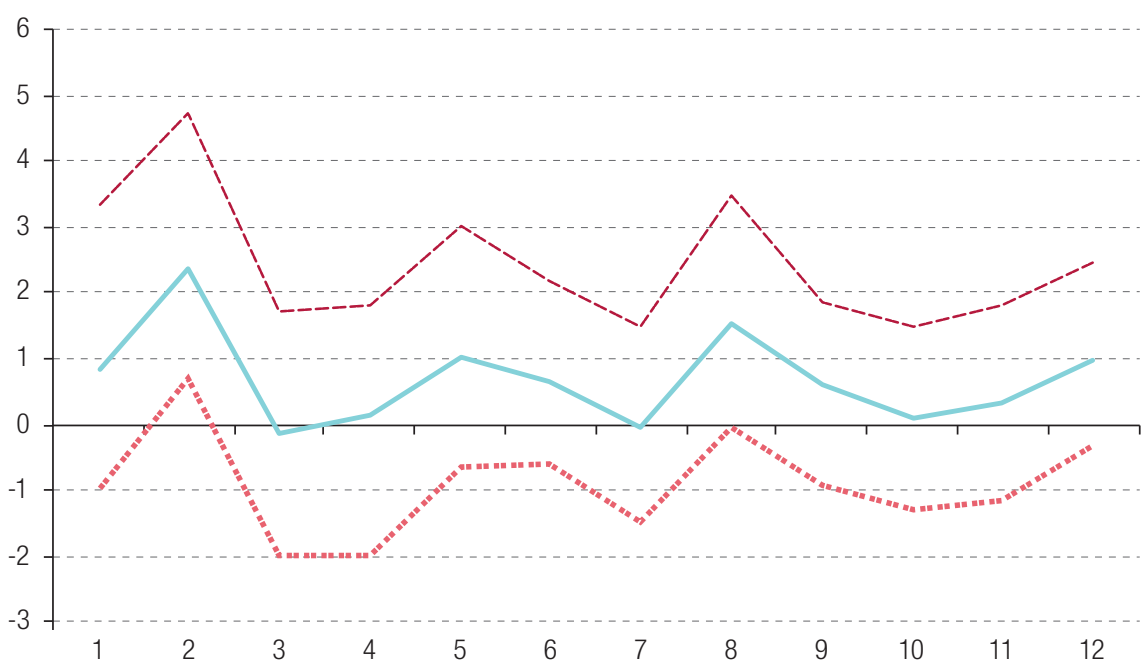

Source: Prepared by the authors, on the basis of data from the National Institute of Statistics and Geography (INEGI) and the Bank of Mexico.

Note: The dotted lines denote a 95\% confidence interval. 


\section{Figure 4}

Response of prices to a wage shock

(Percentage points over a 12-month horizon)

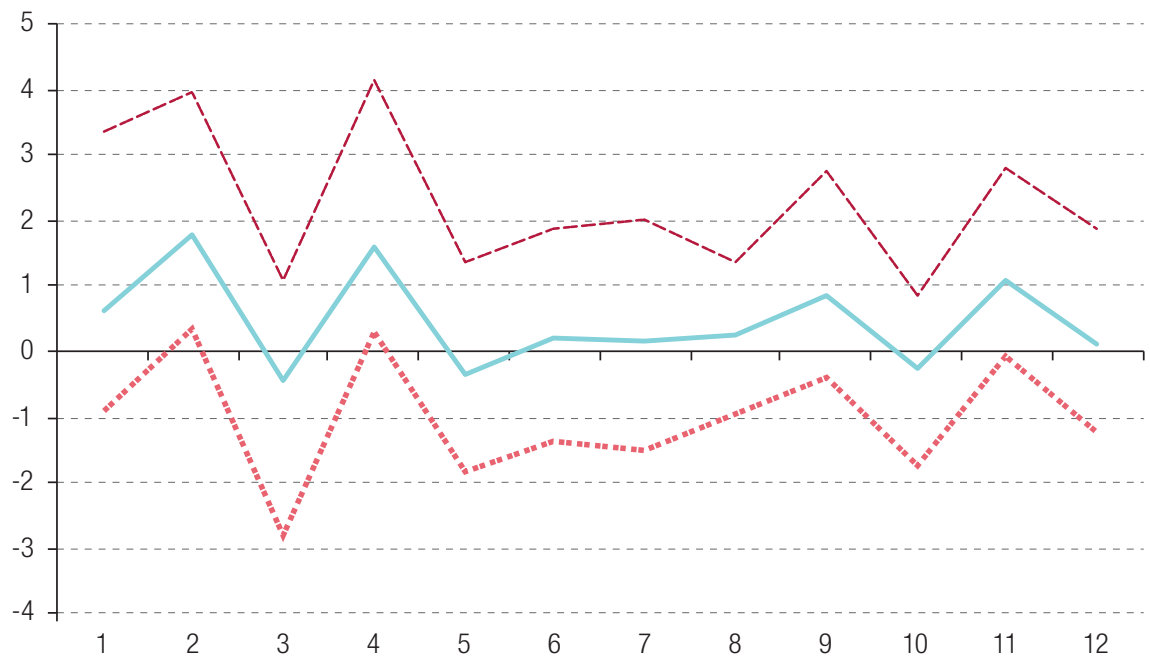

Source: Prepared by the authors, on the basis of data from the National Institute of Statistics and Geography (INEGI) and the Bank of Mexico.

Note: The dotted lines denote a 95\% confidence interval.

Figure 5

Response of prices to a capacity utilization shock (Percentage points over a 12-month horizon)

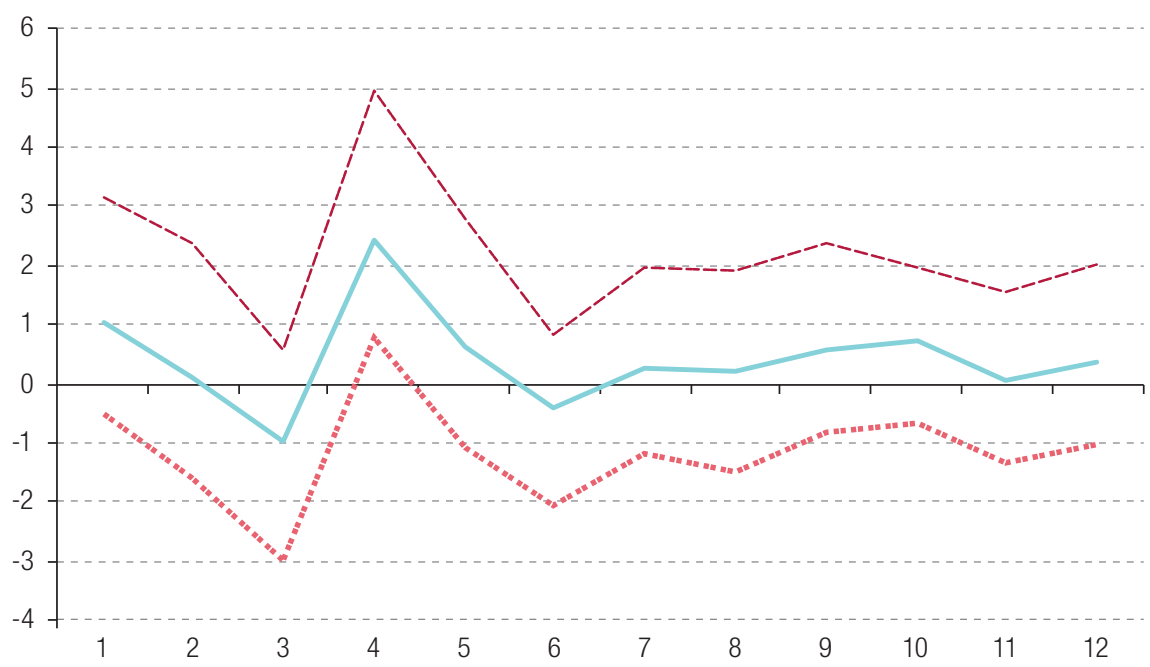

Source: Prepared by the authors, on the basis of data from the National Institute of Statistics and Geography (INEGI) and the Bank of Mexico.

Note: The dotted lines denote a 95\% confidence interval. 


\section{Conclusions}

This paper makes use of an aggregate demand-aggregate supply VEC model to study the long-term drivers of consumer goods prices and industrial output, as well as analysing short-term dynamics. By including a relatively wide range of variables and adopting a long-term approach, we are able to: (i) identify several empirical relationships consistent with economic theory and with some findings of previous research; and (ii) offer new insights into the behaviour of the variables of interest, mainly by bringing labour productivity, wages and United States industrial output into the picture.

The previous empirical literature indicates that the budget deficit, the money supply and the exchange rate, among other variables, are major sources of inflation in Mexico. This research finds that demand-pull and supply-side inflationary pressures are present in the Mexican economy and that higher labour productivity can play a key role in reducing inflation as well as raising output. The long-term evidence on demand-pull inflation is that increased capacity utilization and monetary expansion (i.e. an increase in the monetary base) have a positive impact on prices and production.

The cointegration analysis also shows that raising interest rates is an effective measure for lessening inflationary pressure, given that consumer goods inflation falls as the 28-day rate on government bonds (CETES) goes up. Furthermore, the long-term elasticities indicate that wage increases and exchange-rate depreciation not only raise consumer goods prices but also discourage industrial activity. With regard to exchange-rate depreciation, the implication is that a persistently undervalued exchange rate increases the local currency costs of imported intermediate inputs, capital goods and technology, thereby generating cost-push inflation. The short-term sensitivity analysis, derived from a set of impulse responses with 95\% bootstrapping confidence intervals, is consistent in indicating that exchange-rate depreciation is a source of inflationary pressure. The pass-through effect from the exchange rate to prices, while smaller than in the 1990s, should still be a cause for long-term concern in view of the recurrent speculative attacks on the Mexican peso. A well-known policy recommendation in this regard is to reduce the import content of domestic production by: (i) improving production capacity and efficiency in import-substituting industries; and (ii) strengthening supply- and demand-side chains between these industries and the rest of the economy, especially the export market-oriented sector. Furthermore, exchange-rate policy should be aimed at reconciling the stability required to keep inflation low with the leeway needed to deal with external shocks.

Another important contribution of this paper is to provide significant long-term evidence that labour productivity improvements not only stimulate industrial activity but also reduce inflationary pressures. As stated earlier, Macklem and Yetman (2001) reach a similar finding for the United States and Canadian economies, explaining that productivity growth stabilizes the price level by improving the relationship between economic activity and inflation. Although further research is needed to establish the channel or channels through which workers' productivity influences prices, one possible interpretation of this effect is that a more productive and qualified workforce enhances international competitiveness, thereby making the economy less vulnerable to internal and external shocks. In order to have a more productive workforce, among other measures, Mexico should invest more rather than less in long-term formal schooling, short-term training programmes and the entire knowledge transfer process. Consistent labour productivity growth should be regarded as a means not only to increase industrial activity, but also to enhance price stability in the Mexican economy.

Lastly, United States industrial production exerts a strong influence on Mexican industrial production in both the short and long term. Table 5 and figure 1 show United States industrial output to be the main driver of domestic industrial activity, which reflects the scope and strength of the production chains and trade flows between the United States and Mexico. 


\section{Bibliography}

Agénor, P. and A. Hoffmaister (1997), "Money, wages and inflation in middle-income developing countries", IMF Working Paper, No. 174, Washington, D.C., International Monetary Fund (IMF).

Baqueiro, A., A. Díaz de León and A. Torres (2003), "¿Temor a la flotación o a la inflación? La importancia del traspaso del tipo de cambio a los precios", BM Working Paper, No. 2, Mexico City, Bank of Mexico.

Blanchard, O. and S. Fischer (1990), Lectures on Macroeconomics, Cambridge, MIT Press.

Caldas, G. (2013), "Credibility and monetary transmission channels under inflation targeting: an econometric analysis from a developing country", Economic Modelling, vol. 30, Amsterdam, Elsevier.

Capistrán, C., R. Ibarra and M. Ramos-Francia (2012), "El traspaso de movimientos del tipo de cambio a los precios: un análisis para la economía mexicana", El Trimestre Económico, vol. 79, №. 316, Mexico City, Fondo de Cultura Económica.

Carrasco, C. and J. Ferreiro (2011), "Inflation targeting and economic performance: the case of Mexico", Panoeconomicus, vol. 58, No. 5, Serbia, Savez Ekonomista Vojvodine.

Catalán, H. and L. Galindo (2005), "Los efectos de la política monetaria en el producto y los precios en México: un análisis econométrico", Economía, Sociedad y Territorio, vol. 5, special issue, El Colegio Mexiquense.

Cavazos, G. and S. Rivas-Aceves (2009), "Relación entre la inflación y tasas de interés en México y Estados Unidos", Problemas del Desarrollo, vol. 40, No. 157, Mexico City, National Autonomous University of Mexico (UNAM).

Cheung, Y. W. and K. Lai (1993), "Finite-sample sizes of Johansen's likelihood ratio tests for cointegration", Oxford Bulletin of Economics and Statistics, vol. 55, No. 3, Hoboken, Wiley.

Chiquiar, D., A. Noriega and M. Ramos-Francia (2010), "A time-series approach to test a change in inflation persistence: the Mexican experience", Applied Economics, vol. 42, No. 24, Abingdon, Taylor \& Francis.

Clements, M. and G. Mizon (1991), "Empirical analysis of macroeconomic time series: VAR and structural models", European Economic Review, vol. 35, No. 4, Amsterdam, Elsevier.

Cortés, J. (2013), "Una estimación del traspaso de las variaciones en el tipo de cambio a los precios en México", BM Working Paper, No. 2, Mexico City, Bank of Mexico.

Dornbusch, R., F. Sturzenegger and H. Wolf (1990), "Extreme inflation: dynamics and stabilization”, Brookings Papers on Economic Activity, No. 2, Washington, D.C., The Brookings Institution.

Engle, R. and C. Granger (1987), "Co-integration and error correction: representation, estimation, and testing", Econometrica, vol. 55, No. 2, New York, The Econometric Society.

Esquivel, G. and R. Razo (2003), "Fuentes de la inflación en México, 1989-2000: un análisis multicausal de corrección de errores", Estudios Económicos, vol. 18, No. 2, Mexico City, El Colegio de México.

Garcés, D. (2008), "Efectos de los cambios de la política monetaria en las dinámicas del tipo de cambio, el dinero y los precios en México (1945-2000)", El Trimestre Económico, vol. 75, No. 299, Mexico City, Fondo de Cultura Económica.

Gonzalo, J. (1994), "Five alternative methods of estimating long-run equilibrium relationships", Journal of Econometrics, vol. 60, No. 1-2, Amsterdam, Elsevier.

Guillermo, S. and M. Rodríguez (2014), "Analyzing the exchange rate pass-through in Mexico: evidence post inflation targeting implementation”, Ensayos sobre Política Económica, vol. 32, No. 74, Amsterdam, Elsevier.

Hall, P. (1992), The Bootstrap and Edgeworth Expansion, New York, Springer.

Hamilton, J. (1994), Time Series Analysis, Princeton, Princeton University Press.

Hernández, J. (2015), "Revisión de algunas estimaciones recientes del traspaso del tipo de cambio a los precios en México", Ensayos sobre Política Económica, vol. 33, No. 78, Amsterdam, Elsevier.

Hoover, K., S. Johansen and K. Juselius (2008), "Allowing the data to speak freely: the macroeconometrics of the cointegrated vector autoregression", American Economic Review, vol. 98, No. 2, Nashville, Tennessee, American Economic Association.

Johansen, S. (1995), Likelihood-based Inference in Cointegrated Vector Autoregressive Models, Oxford, Oxford University Press.

Juselius, K. (2011), "The long swings puzzle: what the data tell when allowed to speak freely", Palgrave Handbook of Econometrics, vol. 2, T. Mills and K. Patterson (eds.), New York, Palgrave Macmillan. (2007), The Cointegrated VAR Model: Methodology and Applications, Oxford, Oxford University Press.

Kwiatkowski, D. and others (1992), "Testing the null hypothesis of stationarity against the alternative of a unit root: how sure are we that economic time series have a unit root?", Journal of Econometrics, vol. 54, No. 1-3, Amsterdam, Elsevier. 
MacKinnon, J., A. Haug and L. Michelis (1999), "Numerical distribution functions of likelihood ratio tests for cointegration", Journal of Applied Econometrics, vol. 14, No. 5, Hoboken, Wiley.

Macklem, T. and J. Yetman (2001), "Productivity growth and prices in Canada: what can we learn from the US experience?", BIS Papers, No. 3, Basel, Bank for International Settlements (BIS).

Noriega, A. and M. Ramos-Francia (2009), "Sobre la dinámica de la persistencia de la inflación alrededor del mundo", BM Working Paper, No. 2, Mexico City, Bank of Mexico.

Patterson, K. (2000), An Introduction to Applied Econometrics: A Time Series Approach, London, MacMillan Press Ltd.

Rodríguez, M. (2015), "Tipo de cambio e inflación en México: evidencia del mecanismo de transmisión de precios”, Equilibrio Económico, vol. 11, No. 1, Saltillo, México, Autonomous University of Coahuila.

Rogers, J. and P. Wang (1995), "Output, inflation, and stabilization in a small open economy: evidence from Mexico", Journal of Development Economics, vol. 46, No. 2, Amsterdam, Elsevier.

Rohlf, F. and R. Sokal (1995), Statistical Tables, New York, Freeman.

Tanzi, V. and H. Zee (1997), "Fiscal policy and long-run growth", IMF Staff Papers, vol. 44, No. 2, Washington D.C., International Monetary Fund (IMF).

Tobin, J. (1972), "Wealth, liquidity and the propensity to consume", Human Behavior in Economic Affairs. Essays in Honor of George Katona, G. Katona and others, Amsterdam/New York, Elsevier.

Torres, A. (2000), "Estabilidad en variables nominales y el ciclo económico: el caso de México", BM Working Paper, No. 3, Mexico City, Bank of Mexico.

United States Census Bureau (2007), North American Industry Classification System (NAICS), Maryland.

Vogelsang, T. (1993), "Essays on testing for nonstationarities and structural change in time series models", PhD dissertation, Princeton, Princeton University. 


\section{Annex A1}

The purpose of this annex is to show the transformation of the public sector balance described earlier (see figure A1.1).

Figure A1.1

Scaled version of the public sector balance (Millions of pesos at current prices and natural logarithms)

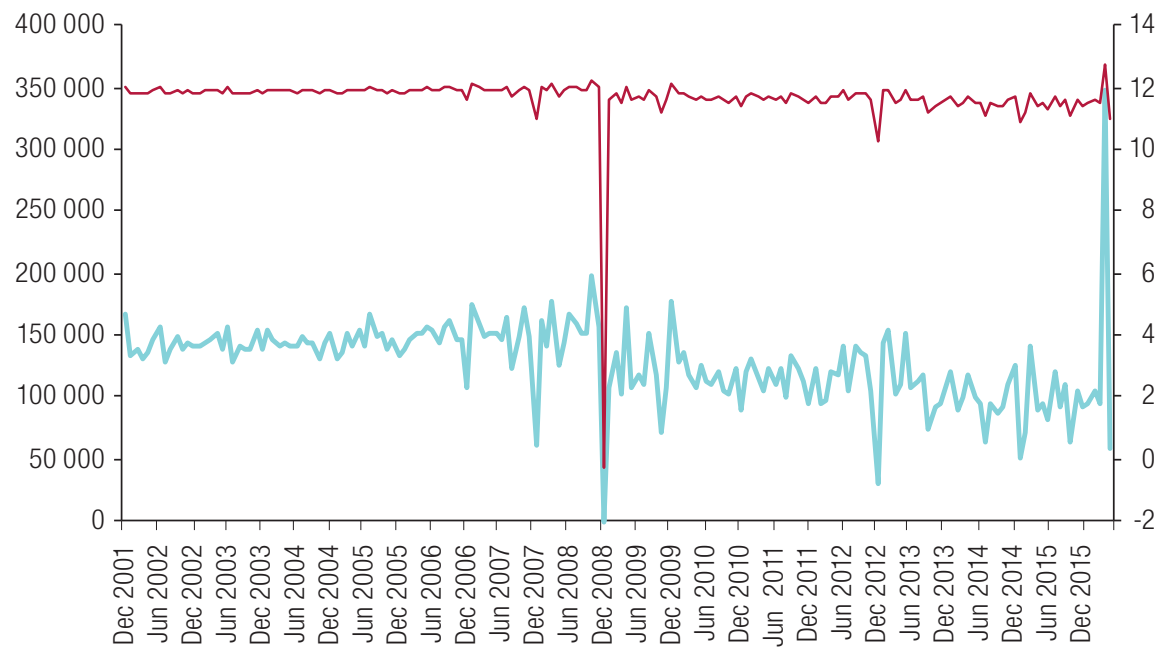

— Millions of pesos at current prices _ _ Natural logarithms

Source: Prepared by the authors, on the basis of data from the National Institute of Statistics and Geography (INEGI) of Mexico. 


\section{Annex A2}

To show that government spending $\left(g_{t}\right)$ is a trend stationary variable, we must first decompose the trend and cyclical components of this variable using the Hodrick-Prescott (HP) filter. If government spending is a trend stationary variable, then its long-run trend is deterministic, and its cyclical component, which is obtained by suppressing the trend from the time series, must be stationary or I(0). When a time series is difference stationary, conversely, it needs to be differentiated once to achieve stationarity (see figure A2.1).

Figure A2.1

Estimation of trend and cyclical components of government spending using the Hodrick-Prescott filter

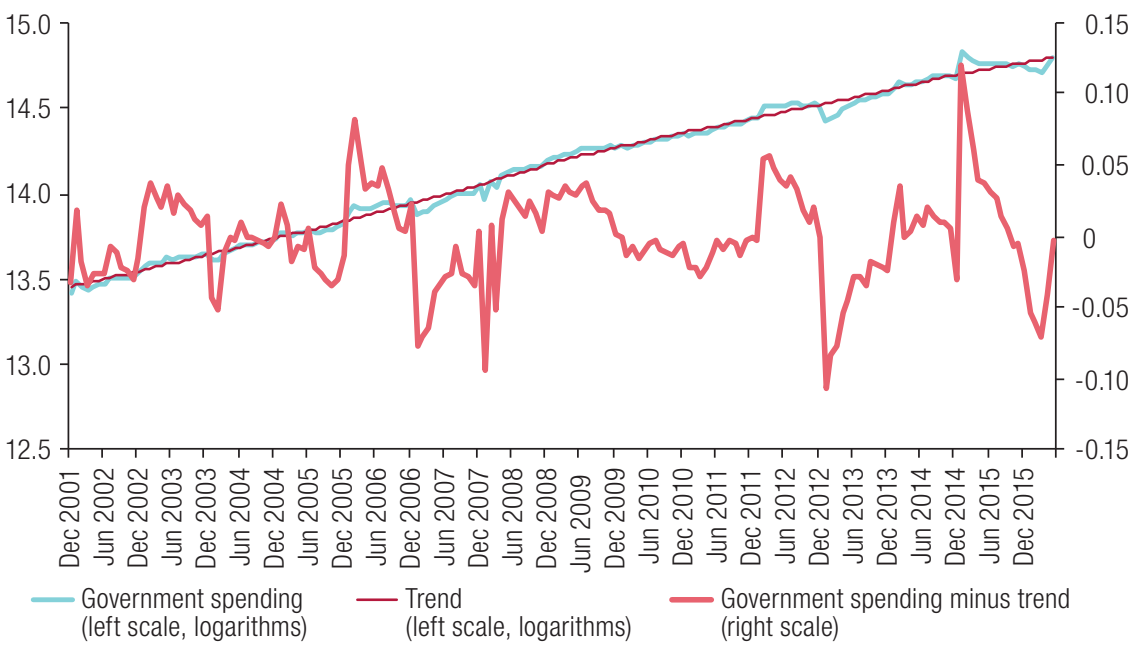

Source: Prepared by the authors, on the basis of data from the National Institute of Statistics and Geography (INEGl) of Mexico.

The next step is to perform breakpoint unit root and stationarity tests on government spending and on its cyclical component, which is referred to as $\left(g_{t}^{c y c l e}\right)$. As table A2.1 shows, although the two types of tests yield conflicting results when applied to government spending $\left(g_{t}\right)$ they point to the same conclusion when it comes to the cyclical component of that spending $\left(g_{t}^{c y c l e}\right)$. The breakpoint unit root test suggests that government spending is stationary, but the stationarity test is inconsistent with this result, given that the null hypothesis of stationarity is rejected for government spending. However, the breakpoint unit root and stationarity tests are consistent in indicating that the cyclical component of government spending $\left(g_{t}^{c y c l e}\right)$ is stationary or $\mathrm{I}(0)$. The null hypothesis of a unit root is rejected at the $1 \%$ level in the first test while the null hypothesis of stationarity is far from being rejected in the second test. Therefore, it is reasonable to conclude that government spending is a trend stationary variable.

Table A2.1

Unit root tests with structural breaks and stationarity tests, December 2001-May 2016

\begin{tabular}{ccccc}
\hline Variable & $\begin{array}{c}\text { Specification of the } \\
\text { test equation }\end{array}$ & $\begin{array}{c}\text { ADF-breakpoint unit root test statistic } \\
\left(\mathrm{H}_{0}: \text { unit root }\right)\end{array}$ & $\begin{array}{c}\text { KPSS test statistic } \\
\left(\mathrm{H}_{0}: \text { stationarity }\right)\end{array}$ & Order of integration \\
\hline$g_{t}$ & $\mathrm{C}$ and T & $-5.6^{\star \star \star}$ & $0.19^{\star \star}$ & $?$ \\
\hline$\left(g_{t}^{\text {cycle }}\right)$ & $\mathrm{C}$ & $-6.16^{\star \star \star}$ & 0.02 & 0 \\
\hline
\end{tabular}

Source: Prepared by the authors, on the basis of data from the National Institute of Statistics and Geography (INEGI) and the Bank of Mexico.

Note: $\quad \mathrm{C}$ stands for constant and T for trend. $\left(g_{t}^{\text {cycle }}\right)$ stands for the cyclical component of government spending. The ADF breakpoint unit root test results rely on Vogelsang (1993) asymptotic one-sided p-values. The lag length of the test equation is determined using the Akaike information criterion. The break type reported here is a level shift, but other possibilities were explored. The break date is estimated from the time series to maximize the likelihood of the unit root null hypothesis being rejected. The KPSS test results are based on the critical values proposed by Kwiatkowski and others (1992). The Newey-West bandwidth selection method and the Bartlett kernel are used to control the bandwidth. Asterisks * ${ }^{\star \star}$ and *** denote rejection of the null hypothesis at the $10 \%, 5 \%$ and $1 \%$ significance levels, respectively. 